\title{
IMPLEMENTASI PELAYANAN KONSELING APOTEKER MODEL SERVQUAL TERHADAP PASIEN KLINIK MUIZZAH DI KECAMATAN RENGAT BARAT, RIAU
}

\section{Oktri Lestari, Lila Wahyuni, Riri Amanda Fitriani, Elza Rachman Panca Priyanda, Ayu Dwi Utami}

Sekolah Tinggi Ilmu Kesehatan Har-Kausyar, Indragiri Hulu, Indonesia

Email: oktrilestari.ol@gmail.com, lylawahyuni93@yahoo.com, ririamandafit@gmail.com, ezarachman9@gmail.com, ayudwi.utami09@gmail.com

\begin{abstract}
Abstrak
Konseling apoteker merupakan komponen yang wajib diberikan oleh apoteker ketika menyerahkan obat kepada pasien. Hal ini termasuk salah satu bentuk Pelayanan di instansi kesehatan yaitu pelayanan kefarmasian. Pelayanan kefarmasian adalah suatu pelayanan langsung dan bertanggung jawab kepada pasien yang berkaitan sediaan farmasi dengan maksud untuk meningkatkan mutu kehidupan pasien. Penilaian terhadap mutu pelayanan kefarmasian dapat dilakukan berdasarkan kepuasan pasien. Penelitian ini menggunakan metode deskriptif kualitatif. Kepuasan pasien terhadap pelayanan konseling apoteker dapat dilakukan dengan menggunakan model SERVQUAL yang memiliki 5 dimensi, yaitu dimensi tangible (bukti nyata), reliability (kehandalan), responsiveness (ketanggapan), assurance (jaminan), dan emphaty (empati). Penelitian ini bertujuan untuk meninjau hasil yang paling menonjol pada 5 dimensi tersebut dan dengan responden sebanyak 40 orang dalam bentuk beberapa pertanyaan (kuesioner). Berdasarkan implementasi konseling apoteker pada pelayanan terhadap pasien di klinik Muizzah menggunakan model SERVQUAL ditemukan dari 5 dimensi tersebut yang paling tinggi adalah Nilai assurance sebanyak 90,1\%. Banyak pasien mengharapkan kompetensi tenaga kefarmasian dapat menanamkan kepercayaan dan keyakinan pada pasien, seperti kinerja apoteker yang berkompeten, professional dan diharapkan dapat memberikan masukan kepada pihak klinik untuk meningkatkan kualitas pelayanan terhadap setiap pasien.
\end{abstract}

Kata Kunci: Konseling Apoteker; Model SERVQUAL; Pelayanan

\section{Abstract}

Pharmacist counseling is a component that must be provided by pharmacists when dispensing drugs to patients. This includes one form of service in health institutions, namely pharmaceutical services. Pharmaceutical service is a direct and responsible service to patients related to pharmaceutical preparations with a view to improving the quality of life of patients. Assessment of the quality of pharmaceutical services can be done based on patient satisfaction. In this study, patient satisfaction with pharmacist counseling services can be done using the SERVQUAL model which has 5 dimensions, namely tangible dimensions (real

$\begin{array}{ll}\text { How to cite: } & \text { Lestari. O., et. al. (2021) Implementasi Pelayanan Konseling Apoteker Model Servqual Terhadap } \\ & \text { Pasien Klinik Muizzah Di Kecamatan Rengat Barat, Riau, Syntax Idea, 3(10), } \\ & \text { https://doi.org/10.36418/syntax-idea.v3i10.1506 } \\ \text { E-ISSN: } & \text { 2684-883X } \\ \text { Published by: } & \text { Ridwan Institute }\end{array}$


Oktri Lestari, Lila Wahyuni, Riri Amanda Fitriani, Elza Rachman Panca Priyanda, Ayu Dwi Utami

evidence), reliability (reliability), responsiveness (responsiveness), assurance (guarantee), and empathy (empathy). This study aims to review the most prominent results on these 5 dimensions and with a total of 40 respondents in the form of several questions (questionnaires). Based on the implementation of pharmacist counseling in services to patients at the Muizzah clinic using the SERVQUAL model, it was found that of the 5 dimensions the highest was the assurance value of 90.1\%. Many patients expect the competence of pharmacists to instill trust and confidence in patients, such as the performance of pharmacists who are competent, professional and are expected to provide input to the clinic to improve the quality of service for each patient.

Keywords: pharmacist counseling; Service; SERVQUAL model

\section{Received: 2021-09-22; Accepted: 2021-10-05; Published: 2021-10-20}

\section{Pendahuluan}

Implementasi kinerja dilakukan oleh sumber daya manusia yang memiliki kemampuan, kompetensi, motivasi dan kepentingan. Bagaimana organisasi menghargai dan memperlakukan sumber daya manusianya akan mempengaruhi sikap dan perilakunya dalam menjalankan kinerja. Salah satu implementasi kinerja dalam bidang kesehatan adalah konseling apoteker (Ramdhani \& Affandi, 2018). Konseling bertujuan memberi edukasi tentang pemahaman pasien terhadap terapi yang dijalaninya, meningkatkan kepatuhan, memotivasi pasien untuk ikut ambil bagian dalam kesehatannya (Harlianti, Andayani, \& Puspandari, 2018). Adanya Informasi obat dan konseling merupakan komponen pharmaceutical care yang wajib diberikan oleh apoteker ketika menyerahkan obat kepada pasien. Informasi tersebut berkaitan dengan penggunaan obat secara tepat, aman dan rasional (Harlianti et al., 2018). Informasi yang disampaikan saat konseling apoteker juga meliputi nama obat, indikasi obat, aturan pemakaian obat, efek samping, penanganan masalah yang dihadapi pasien (Fatiha \& Bintang, 2021). Pemberian edukasi dan pelayanan informasi obat yang dibutuhkan oleh pasien yaitu informasi mengenai instruksi penggunaan obat dengan baik dan benar $(\mathrm{N}$ Putra O, A Damayanti, 2020). Konseling apoteker termasuk salah satu bentuk pelayanan yang harus di tetapkan di rumah sakit maupun di kilinik. Pelayanan di rumah sakit atau di klinik berorientasi kepada akar permasalahan kenapa waktu tunggu pelayanan resep pelayanan pasien, penyediaan obat yang bermutu dan lebih lama dari SPM, menentukan alternatif solusi atas terjangkau bagi semua lapisan masyarakat (Lianti, 2017). Kemampuan seseorang melaksanakan perilaku yang diperlukan untuk memperoleh hasil tertentu, diidentifikasi sebagai prediktor penting dari sejumlah perilaku kesehatan, termasuk dalam kepatuhan minum obat (Farmasi \& Indonesia, 2012). Tingkat kepuasan merupakan suatu luaran humanis yang fokus terhadap pasien serta dapat digunakan sebagai penunjang dalam pengukuran luaran lainnya seperti luaran klinik dan luaran ekonomi (Nugraheni Ambar Yunita, Sari Ika Puspita, 2015). Semakin tingginya tuntutan masyarakat dan semakin berkembangnya pelayanan yang diberikan menuntut apoteker harus mampu memenuhi keinginan dan tuntutan masyarakat yang berubah- 
ubah dan beragam. Akibatnya, dibutuhkan eksistensi apoteker sebagai sumber daya manusia dalam hal peningkatan pengetahuan, keterampilan serta mampu berinteraksi dengan masyarakat (Pratiwi, Mustikaningtias, Widyartika, \& Setiawan, 2020).

Kepuasan pasien adalah suatu tingkat perasaan yang timbul sebagai akibat dari kinerja layanan kesehatan yang diperoleh setelah pasien membandingkan dengan apa yang dirasakan. Pasien akan merasa puas apabila kinerja layanan kesehatan yang diperoleh sama atau melebihi harapan (Sari Dyah Taufika, Sunardi, Astuti Harti, 2019). Waktu pelayanan adalah waktu yang dibutuhkan petugas untuk menyelesaikan satu resep pada setiap proses pelayanan. Sedangkan waktu tunggu adalah waktu tunda sebuah resep tidak dilakukan pelayanan (Sujoko \& Chalidyanto, 2015). Penelitian ini akan dilakukan untuk melihat implementasi konseling apoteker dan hasil dari pelayanan di Klinik Muizzah terhadap pasien. Salah satu caranya adalah dengan menggunakan model SERVQUAL. Salah satu model yang banyak dipakai untuk mengukur kepuasan pelanggan adalah model SERVQUAL (Service Quality) dengan cara membuat survey penilaian kepuasan pelanggan. Analisis kepuasan pelanggan dapat dilakukan berdasarkan lima dimensi kualitas layanan, yakni sebagai berikut: Tangible (bukti nyata) merupakan fasilitas/ sarana fisik yang dapat dilihat atau dirasakan pasien terkait pelayanan yang didapat dibandingkan dengan harapannya. Dalam penelitian ini adalah kemudahan akses lokasi apotek, kecukupan tempat duduk di ruang tunggu, kebersihan dan kenyamanan ruang tunggu. Reliability (kehandalan) merupakan kemampuan tenaga kefarmasian memberikan pelayanan resep yang sesuai dengan harapan pasien. Dalam penelitian ini adalah kemudahan prosedur administrasi pasien menebus obat; Responsiveness (ketanggapan) merupakan dimensi kualitas pelayanan yang paling dinamis, yaitu kecepatan tenaga kefarmasian memberikan pelayanan resep. Assurance (jaminan) merupakan dimensi kualitas yang berhubungan dengan kompetensi tenaga kefarmasian menanamkan kepercayaan dan keyakinan kepada pasien. Emphaty (empati) merupakan suatu kemampuan emosional tenaga kefarmasian untuk mengerti, menolong, dan merasakan apa yang dirasakan pasien. Dalam penelitian ini dimensi emphaty adalah keramahan tenaga kefarmasian memberikan pelayanan kepada pasien tanpa memandang status sosialnya (Prihartini, Yuniar, Susyanty, \& Raharni, 2020). Penelitian ini bertujuan untuk melihat hasil pelayanan di klinik Muizzah dengan menggunakan model SERVQUAL terutama dibidang kefarmasian. Informasi yang didapat diharapkan dapat memberikan masukan kepada pihak klinik Muizzah untuk meningkatkan kualitas pelayanan terhadap setiap pasien.

\section{Metode Penelitian}

Penelitian ini menggunakan metode deskriptif kualitatif. Penelitian deskriptif kualitatif adalah metode yang tidak memberikan perlakuan, manipulasi, atau perubahan variabel bebas, tetapi menggambarkan keadaan sebagaimana adanya (Priscylio, n.d, 2018). Pada jenis penelitian kualitatif digunakan dengan pendekatan narrative. Penambahan pendekatan ini untuk mempermudah teknis penelitian dan memperluas hasil penelitian tersebut. Instrumen pengumpulan data yang digunakan dalam penelitian 
Oktri Lestari, Lila Wahyuni, Riri Amanda Fitriani, Elza Rachman Panca Priyanda, Ayu Dwi Utami

ini berupa kuesioner sebagai instrumen penelitian. Pembuatan kuesioner diadopsi dari beberapa jurnal lalu diterjemahkan ke dalam Bahasa Indonesia. Penyebaran kuesioner dalam penelitian ini melalui media langsung. Penyebaran kuesioner melalui media langsung, peneliti melakukan dengan cara meminta konfirmasi responden untuk mengisi secara langsung. Peneliti mendistribusikan kuesioner penelitian kepada pasien di klinik Muizzah yang bersedia untuk mengisi. Penelitian ini akan menjadi dasar untuk memberikan masukan kepada pihak klinik dalam meningkatkan kualitas pelayanan terhadap setiap pasien di klinik Muizzah.

\section{Hasil dan Pembahasan}

Model Servqual sudah dilakukan dari penelitian terdahulu dan telah banyak menarik minat para peneliti dan praktisi dalam beberapa tahun terakhir ini, para praktisi yakin bahwa kualitas layanan dapat meningkatkan kinerja yang baik (Böttcher et al., 2019). Dinamika yang terjadi saat ini dalam dunia farmasi terutama di bidang instansi kesehatan telah melihat pergeseran ke arah kualitas pelayanan (Mirzae, Dubrovski, Kenneth, Morozov, \& Leshansky, 2018).

Kepuasan dan harapan pasien diukur untuk mengetahui kualitas pelayanan konseling oleh apoteker di apotek dari 5 dimensi, yaitu : tangible, reliability, responsiveness, assurance dan emphaty.

Tabel 1

Distribusi Jenis Kelamin dan Usia di Klinik Muizzah pada bulan Juni 2021 Karakter Pasien Jumlah (n) Persentase (\%)

\begin{tabular}{cllc}
\hline \multicolumn{3}{c}{ Jumlah (n) } & Persentase (\%) \\
\hline \multirow{2}{*}{ Jenis Kelamin } & Laki-laki & $(17)$ & 42,5 \\
& Perempuan & $(23)$ & 57,5 \\
\hline & $20-35$ & $(10)$ & \\
Usia (Tahun) & $36-45$ & $(14)$ & 25 \\
& $46-55$ & $(7)$ & 17,5 \\
& $>60$ & $(9)$ & 22,5 \\
\hline
\end{tabular}

Tabel 2

Kesesuaian Pelayanan Apoteker kepada Pasien pada 5 Dimensi di Klinik Muizzah

\begin{tabular}{clllll}
\hline Dimensi & $\begin{array}{c}\text { No } \\
\text { Kuesioner }\end{array}$ & \multicolumn{1}{c}{ Indikator } & $\begin{array}{c}\mathbf{S} \\
(\mathbf{\%})\end{array}$ & $\begin{array}{c}\text { TS } \\
(\boldsymbol{\%})\end{array}$ \\
\hline & 1 & $\begin{array}{l}\text { Klinik Muizzah menyediakan tempat } \\
\text { khusus untuk pelayanan informasi obat }\end{array}$ & 81,6 & 18,4 \\
Tangibles & 2 & $\begin{array}{l}\text { Klinik Muizzah menyediakan majalah } \\
\text { kesehatan, brosur dan leafleat tentang obat. }\end{array}$ & 70,9 & 29,1 \\
& 3 & Kenyamanan ruang tunggu pasien. & 92,5 & 7,5 \\
\hline Reliability & 4 & $\begin{array}{l}\text { Apoteker memberi tahu indikasi obat yang } \\
\text { diberikan kepada pasien. }\end{array}$ & 80,3 & 19,7 \\
& 5 & $\begin{array}{l}\text { Apoteker memberi tahu aturan pakai obat } \\
\text { yang diberikan kepada pasien. }\end{array}$ & 85,7 & 14,3 \\
& & & &
\end{tabular}


Implementasi Pelayanan Konseling Apoteker Model Servqual terhadap Pasien Klinik Muizzah di Kecamatan Rengat Barat, Riau

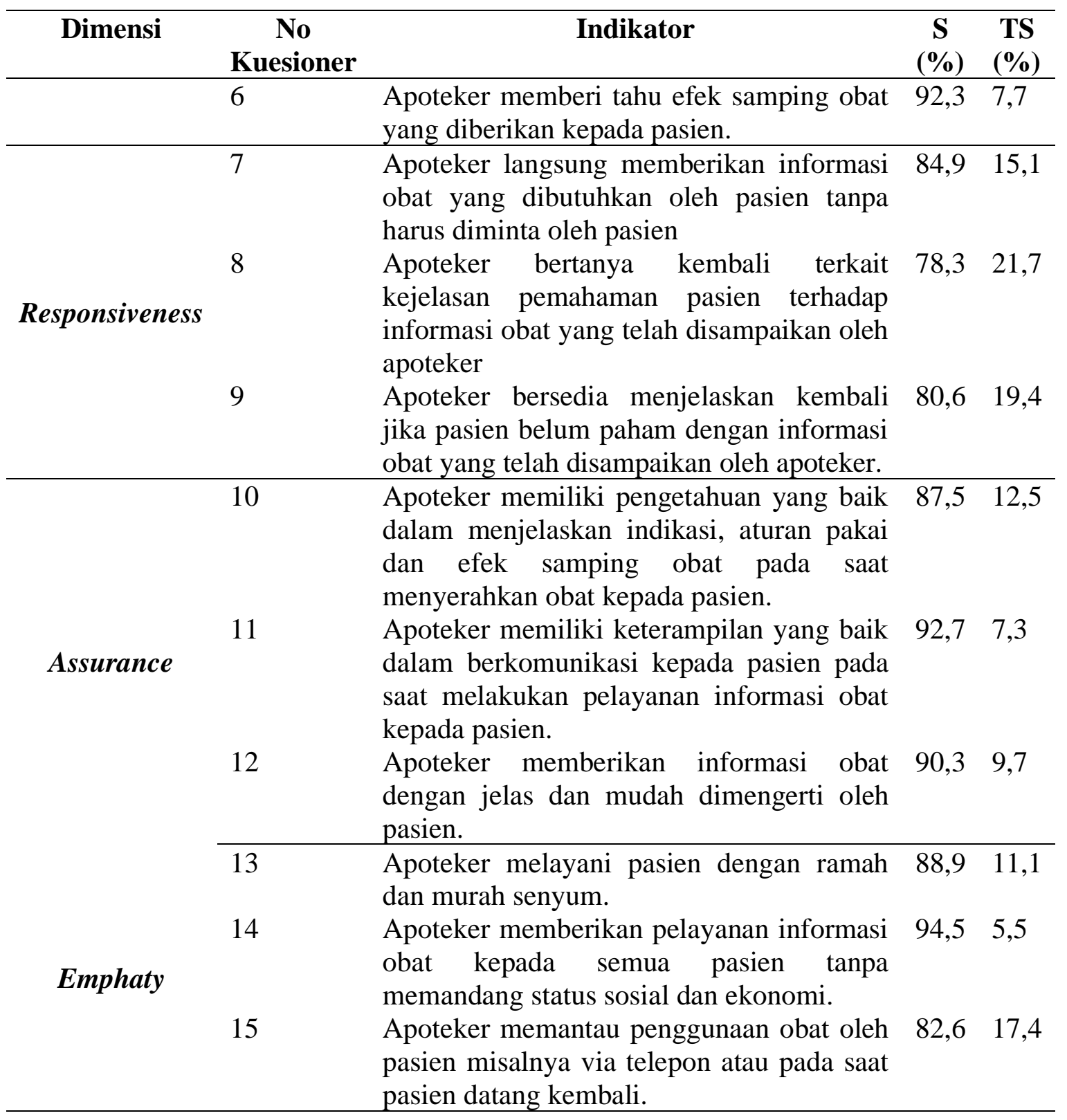

Keterangan :

$\mathrm{S} \quad=$ Sesuai

TS = Tidak Sesuai

Dari data diatas, didapatkan rata-rata pada 5 Dimensi tersebut yang tertera pada tabel dibawah ini.

Tabel 3

Nilai Rata-rata pada 5 Dimensi terhadap pelayanan di Klinik Muizzah

\begin{tabular}{cc}
\hline Dimensi & Nilai Rata-rata $\left(\sum\right) \mathbf{( \% )}$ \\
\hline Tangibles & 81,6 \\
Reliability & 86,1 \\
Responsiveness & 81,2 \\
Assurance & 90,1 \\
Emphaty & 88,6 \\
\hline
\end{tabular}


Oktri Lestari, Lila Wahyuni, Riri Amanda Fitriani, Elza Rachman Panca Priyanda, Ayu Dwi Utami

Tabel 1, dilihat tentang distribusi jenis kelamin dan usia di klinik Muizzah pada bulan Juni 2021. Peneliti melakukan penelitian dengan 40 responden. Namun dapat dilihat pada tabel 2, setiap indikator pada kuesioner sudah ada tanggapan dari responden dengan kriteria jawaban Sesuai (S) maupun Tidak Sesuai (TS). Pada tabel 3 dapat dilihat bahwa dimensi assurance (jaminan) pada pelayanan konseling apoteker di klinik Muizzah memiliki kualitas yang lebih baik dibandingkan dimensi lainnya karena memiliki skor rata-rata tertinggi yaitu 90,1\%, sehingga kompetensi tenaga kefarmasian menanamkan kepercayaan dan keyakinan kepada pasien. Keterampilan dan kemampuan tenaga kefarmasian memberikan informasi obat secara jelas dan lengkap kepada pasien.

Dimensi responsiveness (ketanggapan) perlu mendapat perhatian karena memiliki skor yang paling rendah dengan nilai rata-rata 81,2\%, untuk menghindari semakin menurunnya tingkat kepuasan yang menunjukkan semakin menurunnya kualitas pelayanan konseling oleh apoteker. Kecepatan tenaga kefarmasian di klinik Muizzah masih kurang dalam memberikan pelayanan resep. Oleh karena itu, apoteker harus lebih cepat tanggap lagi dalam memberikan pelayanan terhadap pasien. Nilai rata-rata urutan kedua adalah dimensi emphaty (empati) dengan 88,6\%, urutan ketiga adalah pada dimensi reliability (kehandalan) dengan $86,1 \%$, begitu juga urutan keempat adalah dimensi Tangible (bukti nyata) dengan nilai rata-rata 81,6\%. Konseling untuk meningkatkan kompetensinya. Adanya Kompetensi apoteker dalam proses konseling yang lebih baik diharapkan dapat meningkatkan kepuasan pasien dan kualitas layanan sehingga kepercayaan pasien terhadap apoteker dan apotek meningkat.

\section{Kesimpulan}

Konseling apoteker sangat berpengaruh terhadap pelayanan di klinik Muizzah pada pasien yang ditinjau menggunakan model SERVQUAL. Kelima dimensi pada model servqual tersebut diantaranya dimensi tangibles (bukti fisik) 81,6\%, dimensi reliability (keandalan) 86,1\%, dimensi responsiveness (daya tanggap) 81,2\%, dimensi assurance (jaminan kepastian) 90,1\%, dan dimensi empathy (empati) 88,6\%. Guna meningkatkan kepuasan pasien di klinik Muizzah perlu secara rutin melakukan evaluasi dan monitoring pelayanan kefarmasian, agar dapat mempertahankan kelebihan yang ada dan selalu meningkatkan kualitas pelayanan pada dimensi yang masih kurang dalam standar penilaiannya. Kompetensi tenaga kefarmasian diharapkan juga dapat menanamkan kepercayaan dan keyakinan pada pasien. 
Implementasi Pelayanan Konseling Apoteker Model Servqual terhadap Pasien Klinik Muizzah di Kecamatan Rengat Barat, Riau

\section{BIBLIOGRAFI}

Böttcher, Chotima, Schlickeiser, Stephan, Sneeboer, Marjolein A. M., Kunkel, Desiree, Knop, Anniki, Paza, Evdokia, Fidzinski, Pawel, Kraus, Larissa, Snijders, Gijsje J. L., \& Kahn, René S. (2019). Human microglia regional heterogeneity and phenotypes determined by multiplexed single-cell mass cytometry. Nature Neuroscience, 22(1), 78-90.Google Scholar

Farmasi, Jurnal, \& Indonesia, Klinik. (2012). Dampak Self Efficacy terhadap Perilaku Inovasi Apoteker di Rumah Sakit Impact of Self Efficacy on Innovative Behaviour Pharmacist in Hospital. 1.Corespondesse. Google Scholar

Fatiha, Chilmia Nurul, \& Bintang, Sabiti Farroh. (2021). Peningkatan Kepatuhan Minum Obat Melalui Konseling Apoteker pada Pasien Diabetes Mellitus Tipe 2 di Puskesmas Halmahera Kota Semarang. 41-48. Google Scholar

Harlianti, Mariska Sri, Andayani, Tri Murti, \& Puspandari, Diah Ayu. (2018). Willingness to Pay Pelayanan Konseling Apoteker di Apotek di Kecamatan Polokarto Tahun 2016. 15(1), 1-5. Google Scholar

Lianti, Puji. (2017). Rekredensialing Dalam Program Jaminan Kesehatan Nasional (Jkn) Pada Pelayanan Rawat Jalan Fasilitas Kesehatan Tingkat Pertama (FKTP) Di Kabupaten Jember Tahun 2017. Corespondesse. Google Scholar

Mirzae, Yoni, Dubrovski, Oles, Kenneth, Oded, Morozov, Konstantin I., \& Leshansky, Alexander M. (2018). Geometric constraints and optimization in externally driven propulsion. Science Robotics, 3(17). Google Scholar

N Putra O, A Damayanti, T. Pinani D. (2020). Evaluasi Kepuasaan Pasien Diabetes Mellitus Tipe 2 dengan Hipertensi Terhadap Layanan Kefarmasian di Puskesmas Mulyorejo Surabaya. 8(2), 95-103.

Nugraheni Ambar Yunita, Sari Ika Puspita, Andayani Tri Murti. (2015). Pengaruh Konseling Apoteker Dengan Alat Bantu Pada Pasien Diabetes Melitus. 233-240. Google Scholar

Pratiwi, Hening, Mustikaningtias, Ika, Widyartika, Fajri R., \& Setiawan, Didik. (2020). Analisis Persepsi Masyarakat Terhadap Peran Apoteker Pada Layanan Kefarmasian Di Apotek Kecamatan Sokaraja , Baturraden, Sumbang , Dan. 3348. Google Scholar

Prihartini, Nita, Yuniar, Yuyun, Susyanty, Andi Leny, \& Raharni. (2020). Kepuasan Pasien Rawat Jalan terhadap Pelayanan Kefarmasian di Rumah Sakit dan Puskesmas di 11 Provinsi di Indonesia Outpatient Satisfaction with Pharmaceutical Sevices at Hospital and Primary Health Care in 11 Provinces in Indonesia Peraturan Pemerintah N. 10(1), 42-49. Google Scholar

Priscylio, Ghery. (n.d.). Need of E-Integrated Science Teaching Material Developed 
Oktri Lestari, Lila Wahyuni, Riri Amanda Fitriani, Elza Rachman Panca Priyanda, Ayu Dwi Utami

Using 4S TMD Model For Science Learning and Teaching in Junior High School. Google Scholar

Ramdhani, Rani, \& Affandi, H. Dr Azhar. (2018). Analisis Peningkatan Kinerja Berbasis Komitmen Kerja Di Museum Konferensi Asia Afrika (Mkaa). Perpustakaan Fakultas Ekonomi Dan Bisnis Unpas Bandung. Corespondesse. Google Scholar

Sari Dyah Taufika, Sunardi, Astuti Harti, Susilowati Agustina. (2019). Unit Farmasi Rumah Sakit Santa Elisabeth Ganjuran Bantul. 4(1), 20-24. Google Scholar

Sujoko, Aris, \& Chalidyanto, Djazuly. (2015). Analisis Antrian Pelayanan Obat Non Racikan di Instalasi Farmasi Rawat Jalan. Jurnal Administrasi Kesehatan Indonesia, 3(2), 99-107. Google Scholar

\section{Copyright holder:}

Oktri Lestari, Lila Wahyuni, Riri Amanda Fitriani, Elza Rachman Panca Priyanda, Ayu Dwi Utami (2021)

\section{First publication right:}

Syntax Idea

This article is licensed under:

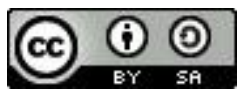

